\title{
Comparison of Azithromycin Removal from Water Using UV Radiation, Fe (VI) Oxidation Process and ZnO Nanoparticles
}

\author{
Amirreza Talaiekhozani ${ }^{1}{ }^{(0)}$, Sahar Joudaki ${ }^{2}$, Farhad Banisharif ${ }^{3}{ }^{(D)}$, Zeinab Eskandari ${ }^{2}$, \\ Jinwoo Cho ${ }^{4}$, Ghasem Moghadam ${ }^{5,6}$ and Shahabaldin Rezania ${ }^{4, *(1)}$ \\ 1 Department of Civil Engineering, Jami Institute of Technology, PO 8491963395, Isfahan, Iran; \\ atalaie@jami.ac.ir \\ 2 Department of Chemical Engineering, Jami Institute of Technology, PO 8491963395, Isfahan, Iran; \\ sahar.joudaki1366@gmail.com (S.J.); zeinabeskandari@jami.ac.ir (Z.E.) \\ 3 School of Chemical, Petroleum and Gas Engineering, Iran University of Science and Technology, \\ P.O. Box 16675-163, Narmak, Tehran, Iran; f.banisharifdehkordey@gmail.com \\ 4 Department of Environment and Energy, Sejong University, Seoul 05006, Korea; jinwoocho@sejong.ac.kr \\ 5 Faculty of Science, Islamic Azad University of Shahrekord branch, P.O. Box 166, Shahrekord, Iran; \\ moghadam.ghasem@gmail.com \\ 6 Young Researchers and Elite Club, Shahrekord Branch, Islamic Azad University, P.O. Box 166, \\ Shahrekord, Iran \\ * Correspondence: Shahab.rezania@sejong.ac.kr or Shahab_rezania89@yahoo.com; Tel.: +82010-2902-1046
}

Received: 27 January 2020; Accepted: 2 March 2020; Published: 8 March 2020

\begin{abstract}
Antibiotics are resistant to biodegradation, and their removal by biological processes is difficult. The purpose of this study was to investigate the removal of azithromycin from water using ultraviolet radiation (UV), $\mathrm{Fe}(\mathrm{VI})$ oxidation process and $\mathrm{ZnO}$ nanoparticles. The effect of different parameters such as $\mathrm{pH}$, temperature, hydraulic retention time (HRT), the concentration of Fe (VI) and $\mathrm{ZnO}$ nanoparticles and UV intensity on the removal of azithromycin from water was investigated. The optimal conditions for the removal of azithromycin were a $\mathrm{pH}$ of 2 , a temperature of $25^{\circ} \mathrm{C}$, a HRT of $15 \mathrm{~min}$, and a ratio of $\mathrm{ZnO}$ nanoparticles to the initial concentration of azithromycin (A/P) of 0.00009 which was fitted by Langmuir isotherm. In addition, the optimal conditions for the removal of azithromycin using UV radiation were a $\mathrm{pH}$ of 7 , a temperature of $65^{\circ} \mathrm{C}$, a HRT of $60 \mathrm{~min}$, and UV radiation power of $163 \mathrm{~mW} / \mathrm{cm}^{2}$. For the $\mathrm{Fe}(\mathrm{VI})$ oxidation process, the optimal conditions were a $\mathrm{pH}$ of 2, a temperature of $50^{\circ} \mathrm{C}$ and a HRT of $20 \mathrm{~min}$. Also, the optimal ratio of Fe (VI) to the initial concentration of antibiotic was between 0.011 and 0.012 . The results of this study showed that the Fe (VI) oxidation process, $\mathrm{UV}$ radiation, and $\mathrm{ZnO}$ nanoparticles were efficient methods for the removal of azithromycin from water.
\end{abstract}

Keywords: Fe (VI) oxidation process; UV radiation; $\mathrm{ZnO}$ nanoparticles; azithromycin removal; wastewater treatment; aquatic antibiotic solution

\section{Introduction}

Nowadays, with the growing population and the expansion of industry, the need for wastewater treatment has become important [1,2]. Wastewater contains several pollutants which are harmful to human and animal health [3]. Pharmaceutical industries produce wastewater containing a wide range of recalcitrant chemicals such as antibiotics that can lead to several environmental issues [4,5]. Antibiotics account for about $15 \%$ of the total drugs produced worldwide and cause the death of microorganisms in wastewater treatment in biological systems such as activated sludge and biotrickling filters [6]. 
The presence of antibiotics in drinking water increases the resistance of pathogenic microorganisms to antibiotics [7]. There are many ways to release antibiotics into water sources such as pharmaceutical industries and human as well as animal stools. Antibiotics are excreted into the wastewater after being used for the treatment of infectious diseases in humans and animals through their feces. Depending on the animal species and the type of antibiotic, between $30 \%$ and $90 \%$ of antibiotics added to animal foods are excreted; a part of this can be released into wastewater [8]. Wei et al. studied the presence of various antibiotics in wastewater and surface water around poultry farms and large-scale livestock in Jiangsu Province, China [9]. They identified sulfamethoxazole, sulfadiazine, tetracycline, sulfamethazine and oxytetracycline as the most predominant antibiotics in that area, with concentrations of 63.6, 17.0, 10.3, 72.9, and $211 \mu \mathrm{g} / \mathrm{L}$, respectively [9]. Yang et al. reported the presence of many antibiotics such as sulfadimethoxine, sulfamethoxazole, sulfachloropyridazine, sulfamethazine, sulfathiazole, meclocycline, doxycycline, chlortetracycline, demeclocycline, tetracycline and oxytetracycline in raw wastewater and treated domestic wastewater [10]. Bhandari et al. reported that the average concentrations for azithromycin, sulfamethoxazole and ciprofloxacin in the raw wastewater in the United State of America were 18.3, 1.11 and $1.44 \mu \mathrm{g} / \mathrm{L}$, respectively [11]. They also reported that the concentrations of azithromycin, sulfamethoxazole and ciprofloxacin in the treated wastewater were $3.25,1.23$, and $0.59 \mu \mathrm{g} / \mathrm{L}$, respectively. Other reports have shown that azithromycin can be found in domestic wastewater [12]. These data show that conventional biological systems for domestic wastewater treatment are not able to remove all antibiotics from wastewater.

Azithromycin is an antibiotic which is widely used in the treatment of bacterial infections such as streptococcal pharyngitis, pneumonia, diarrhea and intestinal inflammation [13]. Antibiotics are not biodegradable but they can be removed from aquatic solutions by physicochemical treatment systems such as electrocoagulation [14], osmotic membrane bioreactor [15] and chemical oxidation processes $[6,16,17]$. The molecular structure of azithromycin is shown in Figure 1.

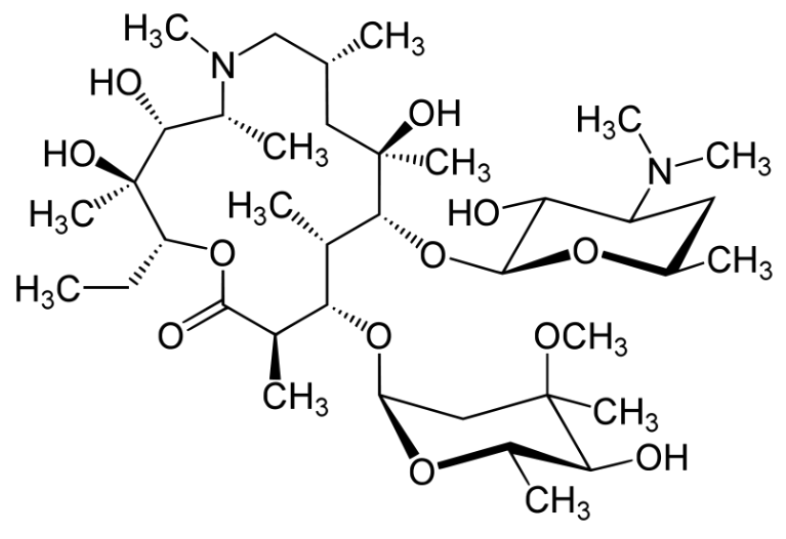

Figure 1. Molecular structure of azithromycin.

Among the various methods of antibiotic removal from aquatic solutions, the use of oxidants such as chlorine [18], ozone [19], chlorine dioxide [20], advanced oxidation methods [21] and Fe (VI) [22] is the most common. Chlorine is a low cost oxidant that can remove antibiotics efficiently, but can also produce dangerous byproducts such as trihalomethanes [23], making it unsuitable for the removal of azithromycin from aquatic solutions. Although oxidizers such as ozone and chlorine dioxide do not produce byproducts, they are expensive. Fe (VI), one of the most powerful oxidizers in acidic conditions, can be produced at low cost, and its usage for the removal of pollutants from aquatic solutions has been considered recently [24]. Fe (VI) is gradually converted to Fe (III), which is a powerful coagulant. Fe (VI) can oxidize organic compounds such as DNA; therefore, it is also considered as a disinfectant [25]. The process of chemical oxidation, coagulation and flocculation, as well as disinfection, can be performed in one unit when a Fe (VI) oxidation process is used [26]. 
UV can degrade the molecules of organic compounds, yielding simpler molecules; therefore, many attempts have been made to use UV for wastewater treatment. Additionally, UV radiation may enhance the activity of photocatalysts such as $\mathrm{MgO}, \mathrm{ZnO}$ and $\mathrm{TiO}_{2}$ [27]. It also used as an activator for several advanced oxidation processes, such as the Fenton process. Thus, the simultaneous usage of UV with other chemical processes can increase the efficacy of the removal of pollutants from water. In this study, the UV radiation method was used for the removal of azithromycin from an aquatic solution [28]. Adsorption is another method used to remove pollutants from aquatic solutions [29,30]. Various absorbents have been introduced for wastewater treatment [31], such as $\mathrm{ZnO}$ nanoparticles. Although $\mathrm{ZnO}$ nanoparticles can adsorb pollutants from water, they can act as a photocatalyst under $\mathrm{UV}$ radiation. In this study, the ability of $\mathrm{ZnO}$ nanoparticles to remove azithromycin from a synthetic aquatic solution was also investigated.

There is no published study on the removal of azithromycin from aquatic solutions with Fe (VI) oxidation process, $\mathrm{UV}$ radiation and $\mathrm{ZnO}$ nanoparticles. Therefore, the objectives of this study were (a) to investigate the ability of the Fe (VI) oxidation process, UV radiation and $\mathrm{ZnO}$ nanoparticles to remove azithromycin from a synthetic aquatic solution, and (b) to investigate the effects of $\mathrm{pH}$, temperature and hydraulic retention time (HRT) on these three methods.

\section{Materials and Methods}

\subsection{Synthetic Aquatic Solution Contaminated with Azithromycin (ASCA)}

To produce ASCA, $2 \mathrm{~g}$ of azithromycin was added to $1000 \mathrm{~mL}$ of distilled water. The solution was then kept in a refrigerator at $4{ }^{\circ} \mathrm{C}$ for $24 \mathrm{~h}$, before being passed through filter paper separate out suspended parts of the antibiotic. Then, the chemical oxygen demand (COD) of filtered ASCA was measured.

\section{2. $\mathrm{ZnO}$ Nanoparticles}

\subsubsection{Effect of $\mathrm{pH}$}

Four Erlenmeyer flasks containing $100 \mathrm{~mL}$ of synthetic ASCA were prepared. Next, different amounts of hydrochloric acid or sodium hydroxide was added to the Erlenmeyer flasks to obtain $\mathrm{pHs}$ of 2, 5, 9 and 12. Then, $0.05 \mathrm{mg} / \mathrm{L} \mathrm{ZnO}$ nanoparticles were added to each of the flasks. Next, the Erlenmeyer flasks were kept at room temperature at $25^{\circ} \mathrm{C}$ for $15 \mathrm{~min}$. In the end, the concentration of COD in each Erlenmeyer flask was determined.

\subsubsection{Effect of $\mathrm{ZnO}$ Nanoparticles}

Five Erlenmeyer flasks with a volume of $250 \mathrm{~mL}$ containing $10 \mathrm{~mL}$ of synthetic ASCA were prepared. Then, a suitable amount of hydrochloric acid $(\mathrm{HCl})$ was added to adjust the $\mathrm{pH}$ on 2 . Next, an appropriate amount of $\mathrm{ZnO}$ nanoparticles was added to flasks 1, 2, 3, 4 and 5 to reach concentrations of $0.01,0.02,0.03,0.04$ and $0.05 \mathrm{mg} / \mathrm{L}$, respectively. After that, the flasks were kept at room temperature at $25^{\circ} \mathrm{C}$ for $15 \mathrm{~min}$.

\subsubsection{Effect of HRT}

The effect of HRT on antibiotic removal by $\mathrm{ZnO}$ nanoparticles was investigated in four different HRTs of 5, 10, 15 and $20 \mathrm{~min}$. In this set of experiments, the $\mathrm{pH}$ was adjusted to 2, the concentration of $\mathrm{ZnO}$ nanoparticles was $0.05 \mathrm{mg} / \mathrm{L}$ and the temperature was $25^{\circ} \mathrm{C}$.

\subsubsection{Effect of Temperature}

A flask containing $100 \mathrm{~mL}$ of synthetic ASCA was prepared. Then, the $\mathrm{pH}$ of synthetic ASCA was adjusted to 2 by adding a suitable amount of hydrochloric acid. The concentration of $\mathrm{ZnO}$ nanoparticles 
was adjusted to $0.05 \mathrm{mg} / \mathrm{L}$. After that, the flask was lept at $25^{\circ} \mathrm{C}$ for $15 \mathrm{~min}$. Next, the COD concentration of the flask was measured. This procedure was repeated at temperatures of of 40,60 and $90{ }^{\circ} \mathrm{C}$.

\subsubsection{Determination of Isotherms}

In this study, the isotherms of Freundlich, Langmuir, D-R, Jovanovic and Generalized were evaluated. Equation (1) shows the linearized Freundlich isotherm.

$$
\log \left(\frac{x}{m}\right)=\log K_{f}+\frac{1}{n} \log \left(C_{e}\right)
$$

where, $x / m$ is the amount of dye adsorbed per weight of the adsorbent under equilibrium condition, $C_{e}$ is the equilibrium concentration of the adsorbed dye in the solution after the adsorption process, $n$ and $K_{f}$ are the constant coefficients of the Freundlich equation. Equation (1) is similar to the general equation of a straight line $(y=a x+b)$. The amount of $K_{f}$ and $n$ can be calculated by plotting $\log (x / m)$ versus $\log \left(C_{e}\right)$. Langmuir isotherm is shown in Equation (2).

$$
\frac{C_{e}}{(x / m)}=\frac{1}{q_{m} K_{e}}+\frac{1}{q_{m}} C_{e}
$$

where $q_{m}$ and $K_{e}$ are Langmuir constants. This equation is similar to the general equation of a straight line $(y=a x+b)$. The values of $a$ and $b$ can be determined by plotting $C_{e} /((x / m))$ versus $C_{e}$. The Temkin isotherm is shown in Equation (3). The constants $K_{T}$ and $B_{1}$ can be calculated using a linear plot of $x / m$ versus $\ln \left(C_{e}\right)$.

$$
x / m=B_{1} \ln \left(K_{T}\right)+B_{1} \ln \left(C_{e}\right)
$$

where $K_{T}$ is the equilibrium binding constant (in L/mg) corresponding to maximum binding energy and the value increased with an increase in temperature for both the adsorbents, which is suggestive of the corresponding increase of maximum binding energy. Constant $B_{1}$ is related to the heat of adsorption [21]. The D-R isotherm, apart from being an analogue of the Langmuir isotherm, is more general than the Langmuir in that it rejects the homogenous surface or constant adsorption potential. The D-R isotherm is shown in Equation (4).

$$
\ln \left(\frac{x}{m}\right)=\ln q_{\max }-\beta \varepsilon^{2}
$$

where $q_{\max }$ is D-R constant and $\varepsilon$ can be calculated using Equation (5).

$$
\varepsilon=R \ln \left(1+\frac{1}{C_{e}}\right)
$$

where $q_{\text {max }}$ is the maximum amount of adsorbate that can be adsorbed on the adsorbent, $B$ is the constant related to energy, $C_{e}$ is the equilibrium concentration (in $\mathrm{mg} / \mathrm{L}$ ), $R$ is a universal gas constant that is equal to $8.314 \mathrm{~J} / \mathrm{mol} . \mathrm{K}$ and $\mathrm{T}$ is the temperature (in Kelvin). The Generalized isotherm is shown in Equation (6).

$$
\ln \left[\left(\frac{q_{\text {max }}}{\frac{x}{m}}\right)-1\right]=\ln \left(K_{G}\right)-N \ln \left(C_{e}\right)
$$

where $K_{G}$ is the saturation constant (in $\mathrm{mg} / \mathrm{L}$ ), $N$ is the cooperative binding constant, $q_{\text {max }}$ is the maximum adsorption capacity of the adsorbent (in $\mathrm{mg} / \mathrm{g}$ ), $\frac{x}{m}$ (in $\mathrm{mg} / \mathrm{g}$ ) and $C_{e}$ (in $\mathrm{mg} / \mathrm{L}$ ) are the equilibrium dye concentrations in the soil and liquid phase, respectively. The values of $N$ and $K_{G}$ are calculated from the slope and intercept of the plots.

Assumptions from the Langmuir model were used to develop Jovanovic Isotherm. In addition to the assumptions of the Langmuir model, the possibility of some mechanical contact between the 
adsorbate and adsorbent was also considered as new for the Jovanovic Isotherm. Equation (7) shows the linear form of the Jovanovic model.

$$
\operatorname{Ln}\left(\frac{x}{m}\right)=\operatorname{Ln}\left(q_{\max }\right)-K_{J} C_{e}
$$

where $C_{e}$ is the equilibrium concentration (in $\mathrm{mg} / \mathrm{L}$ ), $K_{J}$ is constant coefficient of Jovanovic, $\frac{x}{m}$ is the amount of adsorbate that was adsorbed at the equilibrium stage $(\mathrm{mg} / \mathrm{g})$, and $q_{\max }$ is the maximum uptake of adsorbate obtained from the plot of $\ln \frac{x}{m}$ versus $C_{e}$.

\subsection{UV Radiation}

Since UV radiation does not have the ability to pass through glass, containers with a length of $20 \mathrm{~cm}$, a width of $5 \mathrm{~cm}$ and a depth of $2 \mathrm{~cm}$ were used for the experiments. A UV lamp was installed a few millimeters away from the surface of the synthetic ASCA.

\subsubsection{Effect of $\mathrm{pH}$}

UV containers containing $100 \mathrm{~mL}$ of synthetic ASCA were prepared. The $\mathrm{pH}$ of the UV container was adjusted to 2. Next, the UV container was exposed to UV radiation with a power of $163 \mathrm{~mW} / \mathrm{cm}^{2}$ at $25{ }^{\circ} \mathrm{C}$ for $15 \mathrm{~min}$. After that, this experiment was repeated for $\mathrm{pHs}$ of 5, 9, 11 and 13. Then, the concentration of COD in all UV containers was measured.

\subsubsection{Effect of Temperature}

Six UV containers containing $100 \mathrm{~mL}$ of synthetic ASCA were prepared. By adding a suitable amount of hydrochloric acid. the $\mathrm{pH}$ of the UV containers was adjusted to 2 . Then, containers $1,2,3,4$, 5 and 6 were exposed to UV radiation with a power of $163 \mathrm{~mW} / \mathrm{cm}^{2}$ at temperatures of $25,35,55,65,75$ and $85^{\circ} \mathrm{C}$ for $15 \mathrm{~min}$, respectively.

\subsubsection{Effect of HRT}

Four UV containers containing $100 \mathrm{~mL}$ of synthetic ASCA were prepared. By adding an appropriate amount of hydrochloric acid, the $\mathrm{pH}$ of the synthetic ASCA was adjusted to 2 . The UV containers were then exposed to UV radiation at $163 \mathrm{~mW} / \mathrm{cm}^{2}$ at $25^{\circ} \mathrm{C}$ for $20 \mathrm{~min}$. This experiment was repeated in HRTs at 30, 35, 50 and $80 \mathrm{~min}$.

\subsubsection{Effect of UV Radiation}

A UV container containing $100 \mathrm{~mL}$ of synthetic ASCA was prepared. Then, by adding an appropriate amount of hydrochloric acid, the $\mathrm{pH}$ of the synthetic ASCA was adjusted to 2. Next, the container was exposed to UV radiation with a power of $163 \mathrm{~mW} / \mathrm{cm}^{2}$ at $25{ }^{\circ} \mathrm{C}$ for $60 \mathrm{~min}$. Finally, the amount of COD of synthetic ASCA was measured. This experiment was repeated with UV radiations of $103,118,133,148$, and $163 \mathrm{~mW} / \mathrm{cm}^{2}$.

\section{4. $\mathrm{Fe}(\mathrm{VI})$}

\subsubsection{Production of Ferrate (VI)}

In this study, the method introduced by [32] was used to produce Fe(VI). Based on Figure 2, two rectangular iron pieces of with thicknesses of $0.63 \mathrm{~mm}$ and dimensions of $60 \times 24 \mathrm{~mm}$ were used as the cathode and anode electrodes. The electrical power supplier used in this study was able to produce a $\mathrm{DC}$ voltage of between 1 and $24 \mathrm{~V}$. The details of the $\mathrm{Fe}(\mathrm{VI})$ generator are presented in Figure 2 . In this study, $14 \mathrm{M}$ (56 g) sodium hydroxide solution was added to $100 \mathrm{~mL}$ of distilled water. Then, $100 \mathrm{~mL}$ of $14 \mathrm{M}$ sodium hydroxide was added to the $\mathrm{Fe}(\mathrm{VI})$ generator. Subsequently, the electrodes were charged 
with a DC current with a voltage of $9 \mathrm{~V}$ and an amperage of $1 \mathrm{~A}$ for $30 \mathrm{~min}$. As the $\mathrm{Fe}(\mathrm{VI})$ was gradually converted to $\mathrm{Fe}(\mathrm{III})$, the produced $\mathrm{Fe}(\mathrm{VI})$ solution was used in the experiments as quickly as possible.

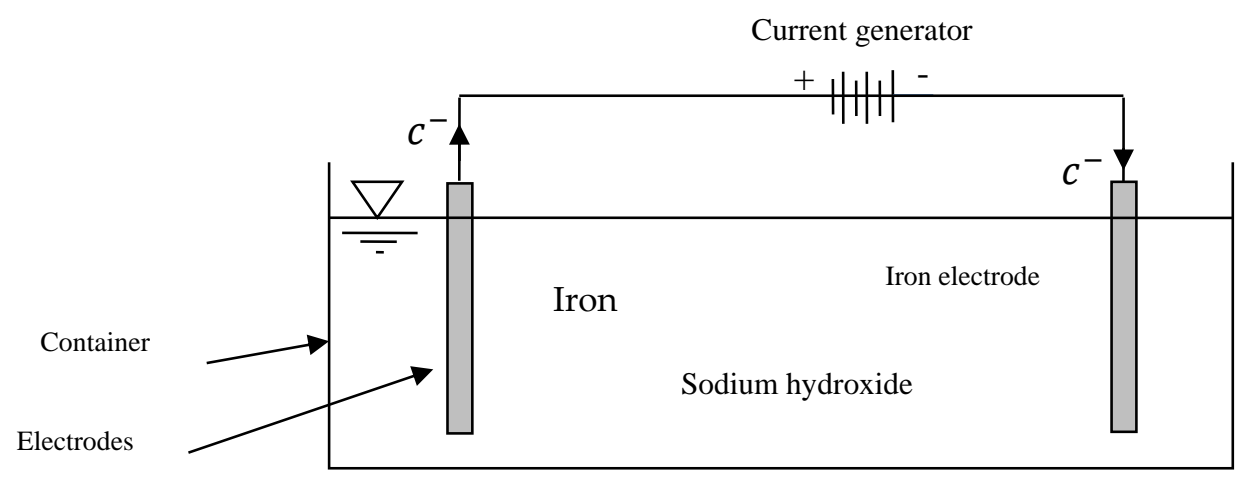

Figure 2. Schematic of the electrochemical cell for ferrate (VI) synthesis.

\subsubsection{Effect of $\mathrm{pH}$}

Five $250 \mathrm{~mL}$ Erlenmeyer flasks containing $100 \mathrm{~mL}$ of synthetic ASCA were prepared. Then, a concentration of $2.53 \mathrm{mg} / \mathrm{L} \mathrm{Fe}(\mathrm{VI})$ was prepared. Next, by adding a suitable amount of hydrochloric acid or sodium hydroxide, the pHs of flasks 1, 2, 3, 4 and 5 were adjusted to 2, 5, 7, 9 and 13, respectively. After that, the flasks were kept at $25^{\circ} \mathrm{C}$ for $15 \mathrm{~min}$.

\subsubsection{Effect of Fe (VI) Concentration}

Four Erlenmeyer flasks with a volume of $250 \mathrm{~mL}$ containing $100 \mathrm{~mL}$ of synthetic ASCA were prepared. Then, the $\mathrm{pH}$ of the flasks was adjusted to 2 . Next, adding a suitable amount of Fe (VI) to flasks 1, 2, 3, and 4, the concentration of Fe (VI) was adjusted to 0.09, 1.2, 2, 2.2 and $2.5 \mathrm{mg} / \mathrm{L}$. After that, the Erlenmeyer flasks were maintained at $25^{\circ} \mathrm{C}$ for $15 \mathrm{~min}$.

\subsubsection{Effect of HRT}

Four $250 \mathrm{~mL}$ Erlenmeyer flasks containing $100 \mathrm{~mL}$ of synthetic ASCA were prepared. Then, the $\mathrm{pH}$ of the Erlenmeyer flasks was adjusted to 2. Next, a suitable amount of Fe (VI) was added to each of the flasks to reach a Fe (VI) concentration of $2.5 \mathrm{mg} / \mathrm{L}$. After that, flasks of 1 to 4 were kept at $25^{\circ} \mathrm{C}$ for a period of 10 to $25 \mathrm{~min}$.

\subsubsection{Effect of Temperature}

Four $250 \mathrm{~mL}$ Erlenmeyer flasks containing $100 \mathrm{~mL}$ of synthetic ASCA were prepared. Then, the $\mathrm{pH}$ was adjusted to 2 . Next, an appropriate amount of $\mathrm{Fe}(\mathrm{VI})$ was added to each of the flasks to reach a $\mathrm{Fe}(\mathrm{VI})$ concentration of $2.38 \mathrm{mg} / \mathrm{L}$. After that, flasks of 1 to 4 were kept at a temperature of 25, 40,50 and $60^{\circ} \mathrm{C}$, respectively, for $20 \mathrm{~min}$.

\subsection{Analytical Methods}

All chemicals except $\mathrm{ZnO}$ nanoparticles, azithromycin and $\mathrm{Fe}(\mathrm{VI})$ were purchased from the Merck Company. ZnO nanoparticles were purchased from Sigma-Aldrich Company. Based on the information provided by this company, the size of the $\mathrm{ZnO}$ nanoparticles was $<50 \mathrm{~nm}$. Analytical grade azithromycin was purchased from Sigma, Malaysia. In this study, $\mathrm{Fe}(\mathrm{VI})$ was prepared by the electrochemical method according to the instructions described in [33]. A digital pH meter, the AZ-86502 (Taiwan) was used to measure the $\mathrm{pH}$. The power of UV radiation was measured using a 340A UV meter (Taiwan). Equation (8) was used to determine the efficiency of antibiotic removal from the water 
in all experiments. The amount of antibiotic was determined by a COD test. The COD was measured by APHA standard method [34].

$$
R E=\frac{C_{1}-C_{2}}{C_{1}} \times 100
$$

\section{Results}

The effect of $\mathrm{pH}$ changes on the removal efficiency of the antibiotic by $\mathrm{ZnO}$ nanoparticles is shown in Figure 3a. As shown, $\mathrm{pH}$ and antibiotic removal have an inverse relationship, i.e., an increase in $\mathrm{pH}$ causes a decrease in antibiotic removal. The effects of different temperatures on antibiotic adsorption by $\mathrm{ZnO}$ nanoparticles are shown in Figure $3 \mathrm{~b}$. This figure shows that at lower temperatures, the antibiotic was better removed by the $\mathrm{ZnO}$ nanoparticles. The effect of HRT changes on the antibiotic removal efficiency of $\mathrm{ZnO}$ nanoparticles is shown in Figure 3c, and the effect of different concentrations of nanoparticles on antibiotic removal efficiency is shown in Figure 3d. The results showed that increasing both HRT and ZnO nanoparticle dosage had a positive effect on antibiotic removal.
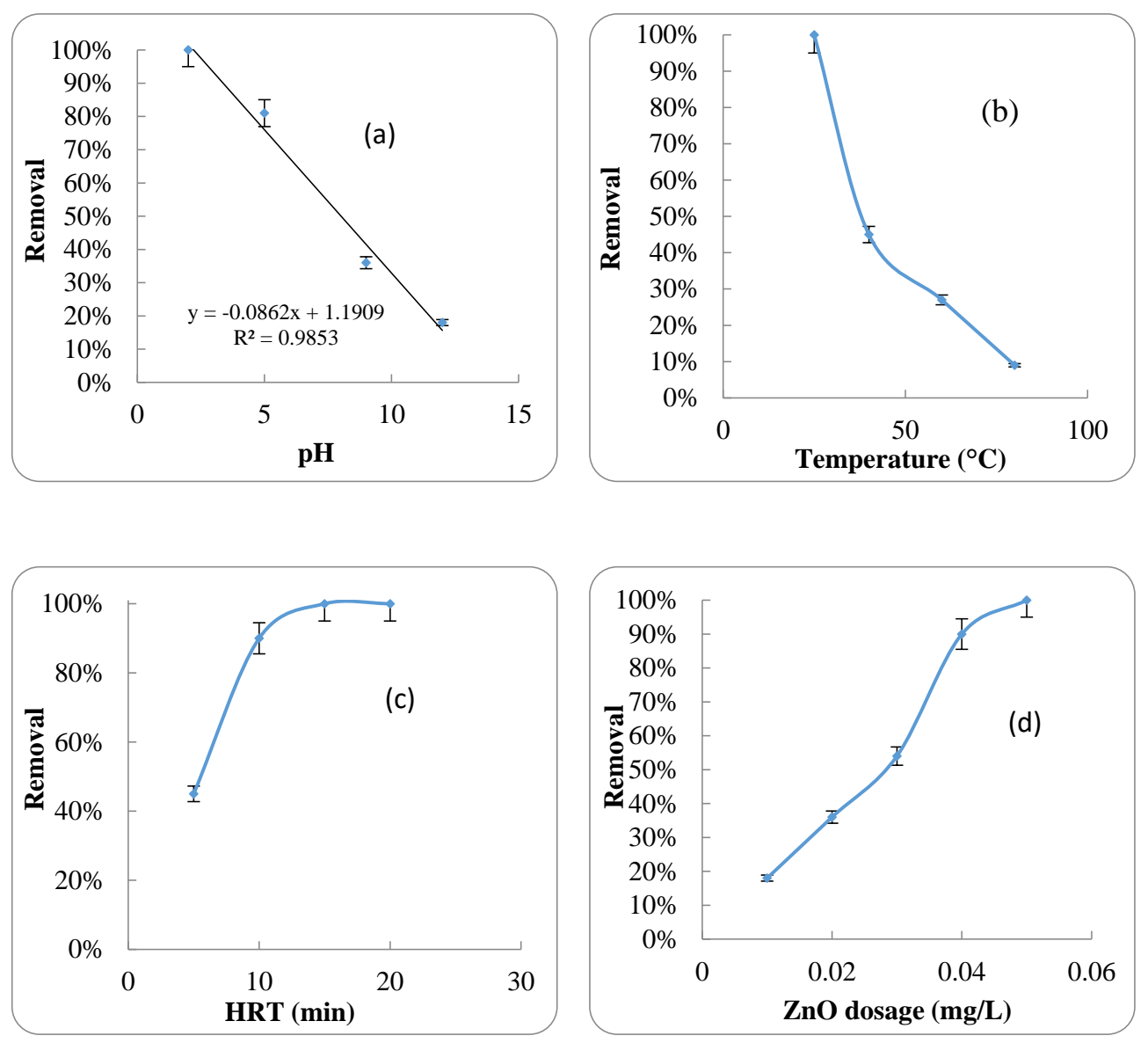

Figure 3. (a) Effect of $\mathrm{pH}$ changes on the removal efficiency of the antibiotic by $\mathrm{ZnO}$ nanoparticles; (b) the effects of different temperatures on antibiotic adsorption by $\mathrm{ZnO}$ nanoparticles; (c) the effect of HRT changes on the antibiotic removal efficiency by $\mathrm{ZnO}$ nanoparticles and (d) the effect of different concentrations of $\mathrm{ZnO}$ nanoparticles on antibiotic removal efficiency.

In this study, the Langmuir, Freundlich, D-R, Temkin, Genalized, and Jovian isotherms for the removal of an antibiotic from synthetic ASCA were investigated. The regression of these isotherms and their correlation coefficients are shown in Figure 4a-f. 


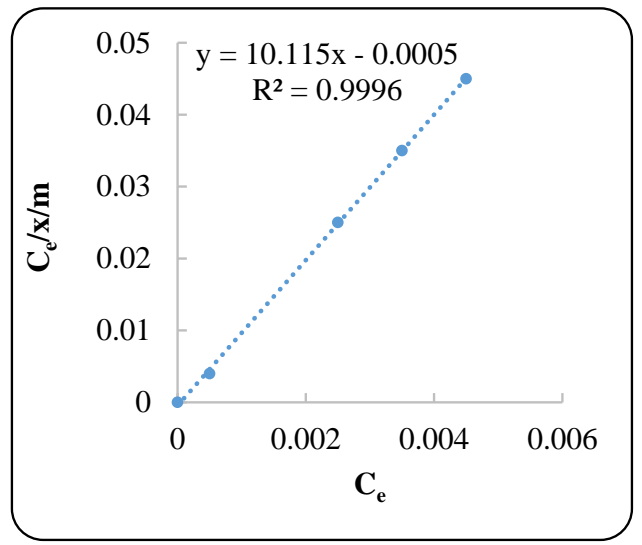

(a) Langmuir isotherm

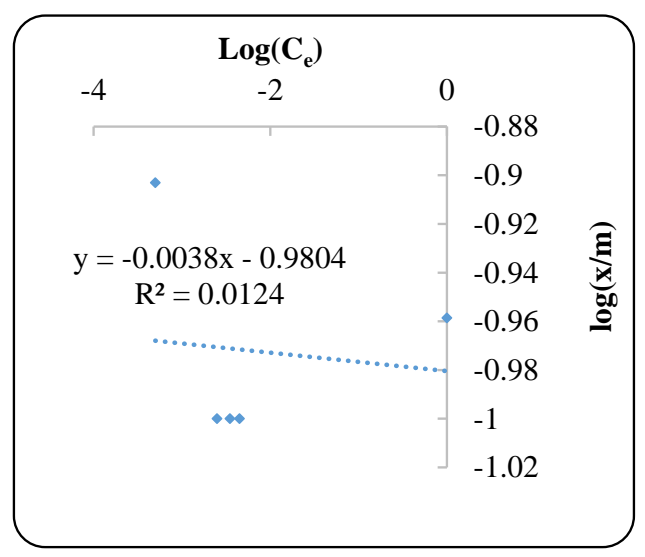

(c) Freundlich isotherm

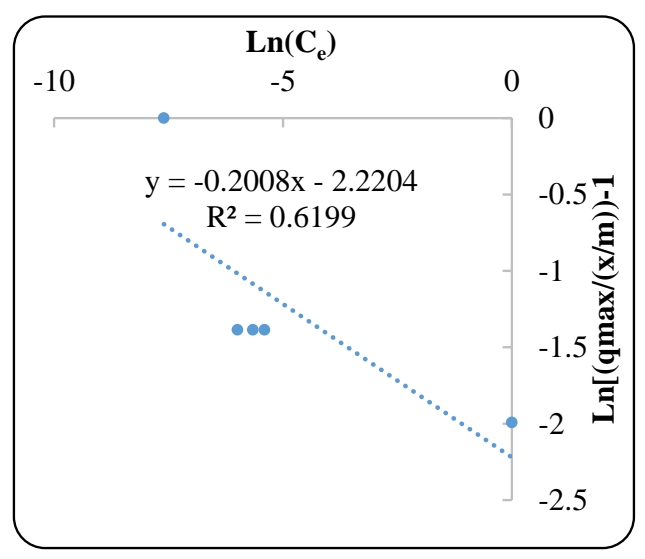

(e) Generalized isotherms

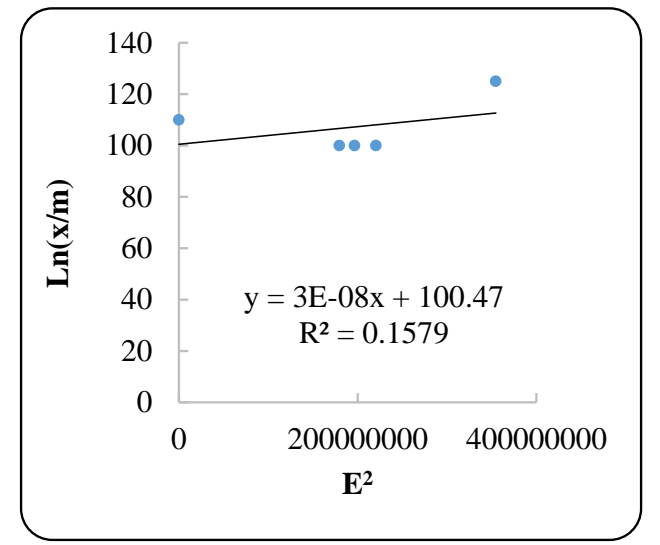

(b) D-R isotherm

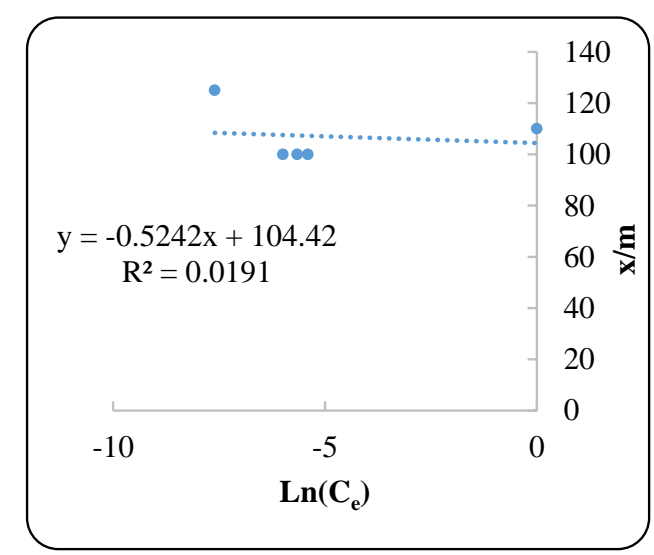

(d) Temkin isotherm

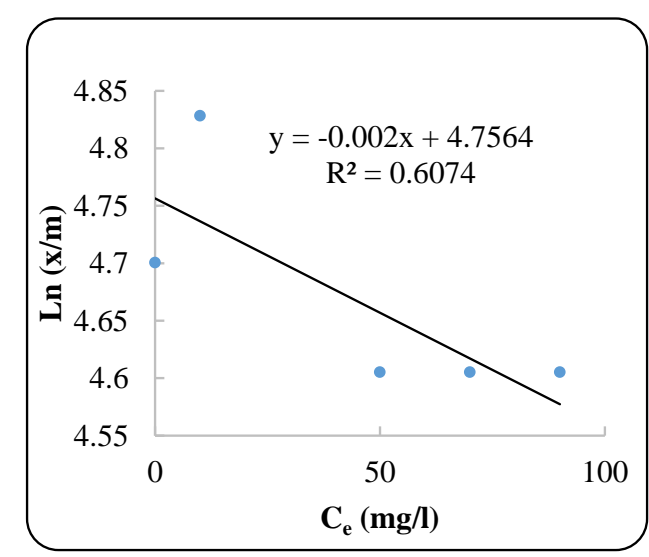

(f) Jovanovic Isoterm

Figure 4. (a-f) The regression of Langmuir, D-R, Freundlich, Temkin, Generalized, and Jovian isotherms for removal of antibiotic from synthetic ASCA.

The effect of different $\mathrm{pHs}$, temperature, HRT and UV radiation power on antibiotic removal efficiency by UV radiation is shown in Figure 5.

Another part of this study was related to antibiotic removal using Fe (VI); therefore, the effect of $\mathrm{pH}$, temperature, HRT and Fe (VI) concentration on antibiotic removal efficiency by Fe (VI) was investigated. The results are shown in Figure 6. 

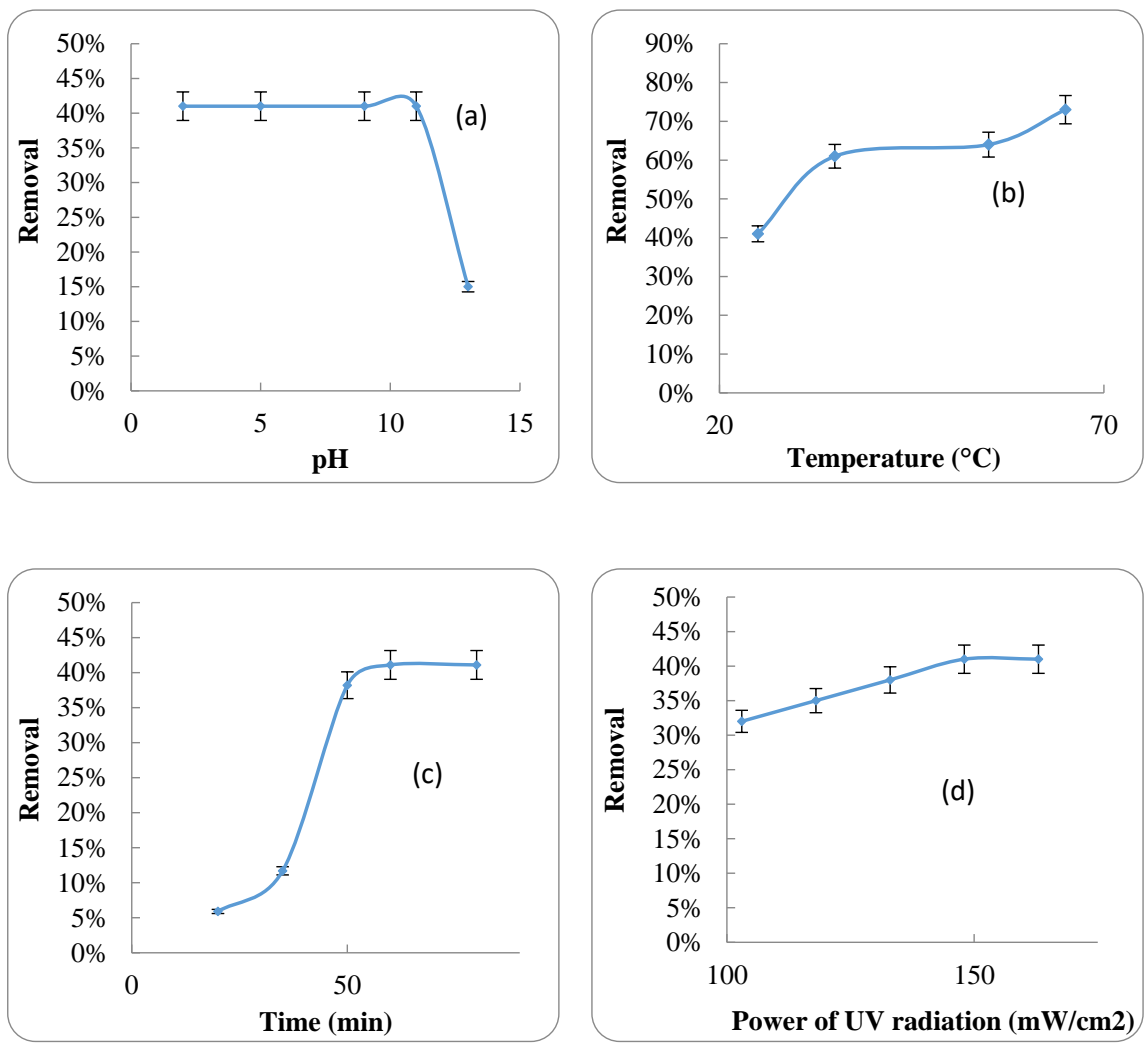

Figure 5. The antibiotic removal by UV radiation (a) The effect of different pHs; (b) The effect of temperature change; (c) The effect of HRT (d) The effect of UV radiation power.
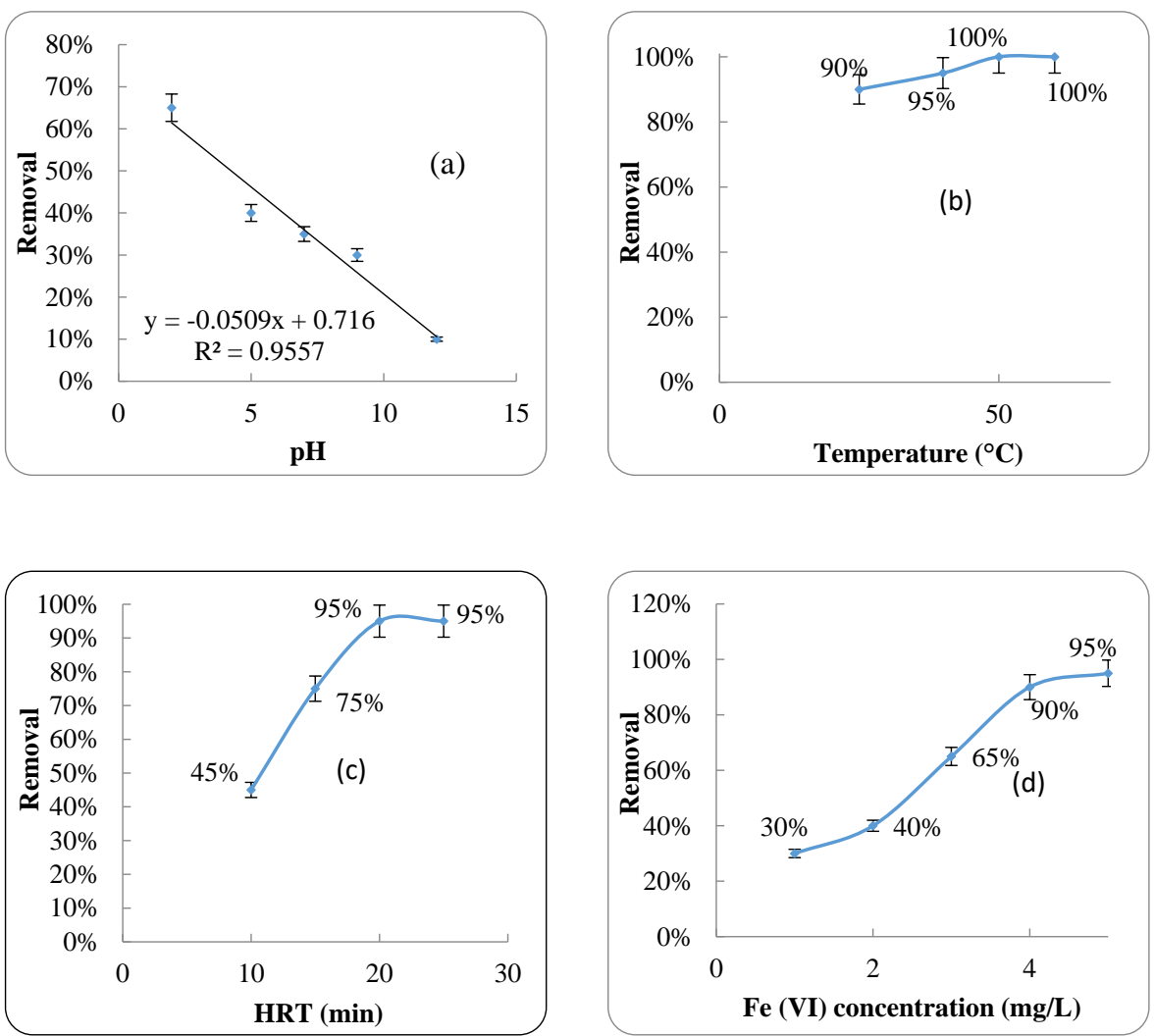

Figure 6. Antibiotic removal efficiency by Fe (VI); (a) The effect of $\mathrm{pH}$; (b) The effect of temperature; (c) The effect of HRT; and (d) The effect of Fe(VI) concentration. 


\section{Discussion}

\subsection{ZnO Nanoparticles}

$\mathrm{pH}$ has been introduced as an effective parameter in the absorption process [35]. In acidic $\mathrm{pH}$, hydrogen cations (protons) absorbs electron pairs of etheric oxygen which are between the aromatic ring and chair structure because of their empty orbitals [36]. Thus, the chair structure becomes separated from the aromatic ring and the hydroxyl group replaces it. The break-down of both bonds of etheric oxygen is dependent on the temperature and entropy of the system. Under a basic $\mathrm{pH}$, the hydroxyl group of the reaction ambient can completely separate both chair-like structures from the aromatic ring. So, the aromatic ring will contain aldehyde group and both chair-like structures will have a hydroxyl group. All of the produced structures have a negative charge under a basic $\mathrm{pH}$.

As stated, the $\mathrm{pH}$ of the zeta point of $\mathrm{ZnO}$ nanoparticles is 9; the surface of $\mathrm{ZnO}$ may be positive in pHs below 9 and negative in pHs greater than 9 [37]. Therefore, it is possible to predicte the maximum efficiency of adsorption to be achieved under a strong acidic $\mathrm{pH}$ if a breakdown of etheric bonds is incomplete and the antibiotic has a negative charge.

Based on these results, by increasing the pH of ASCA, the amount of absorbed antibiotic on the $\mathrm{ZnO}$ nanoparticles was reduced (Figure 3a). The highest antibiotic absorption efficiency was $99.9 \%$ at a $\mathrm{pH}$ of 2 . By increasing the $\mathrm{pH}$ from 2 to 5 , the absorption efficiency decreased to $81 \%$. At $\mathrm{pH} 13$, only $18 \%$ of the antibiotic was absorbed. Therefore, the relationship between antibiotic adsorption efficiency and $\mathrm{pH}$ at $25^{\circ} \mathrm{C}$, a HRT of $15 \mathrm{~min}$, an antibiotic concentration $110 \mathrm{mg} / \mathrm{L}$ and a $\mathrm{ZnO}$ nanoparticle concentration of $0.05 \mathrm{mg} / 1$ can be described by Equation (9).

$$
y=-0.0862 x+1.1909\left(R^{2}=0.98\right)
$$

In this equation, $\mathrm{y}$ is the efficiency of the antibiotic adsorption (\%) and $\mathrm{x}$ is the $\mathrm{pH}$ of the synthetic ASCA. As reported by [38], 42\% to 50\% of Ciprofloxacin can be removed at pHs between 7 and 10 using $\mathrm{ZnO}$ nanoparticles. Temperature is another effective parameter in the absorption process [39]. As shown in Figure 3b, increasing the temperature had a negative effect on the adsorption efficiency of antibiotic by $\mathrm{ZnO}$ nanoparticles. At $25^{\circ} \mathrm{C}$, more than $99.9 \%$ of the antibiotic was adsorbed from the ASCA by $\mathrm{ZnO}$ nanoparticles. However, by increasing the temperature, the adsorption efficiency decreased sharply. In addition, only $40 \%$ and $9 \%$ of antibiotic were adsorbed by $\mathrm{ZnO}$ nanoparticles at $40^{\circ} \mathrm{C}$ and $90^{\circ} \mathrm{C}$, respectively. It can be noted that if the amount of absorption increases with increasing temperature, the process of absorption is endothermic. This is due to the increase in the mobility of the absorbed molecules and an increase in the number of active adsorption sites at higher temperatures [40]. In contrast, by increasing in temperature, the absorption efficiency decreases, which shows that the adsorption is an exothermic process. It is caused by an increase in the absorption force between a specific material and active sites on the surface of the adsorbent by temperature increase [40]. Therefore, in this study, the azithromycin adsorption process with $\mathrm{ZnO}$ nanoparticles was an exothermic process.

The results also prove that only one of the two etheric oxygen bonds could be broken at low temperatures, low entropies and acidic pHs. So, the electric charge of the antibiotic is negative and it can be adsorbed by the positively-charged surface of the nanoparticles under acidic conditions. It can be assumed that as the entropy of the system increases by increasing the temperature, both etheric groups may be broken, and the antibiotic would become relatively positively-charged. Therefore, the efficiency of adsorption of the antibiotic on the positively-charged surface of the $\mathrm{ZnO}$ nanoparticles can be increased [41,42].

The concentration of nanoparticles is also a major parameter for the efficiency of antibiotic adsorption [43]. The results showed that by increasing the concentration of $\mathrm{ZnO}$ nanoparticles from 0.01 to $0.05 \mathrm{~g} / \mathrm{L}$, the antibiotic adsorption efficiency increased from $18 \%$ to $99.9 \%$. It was found that the highest adsorption efficiency was achieved when the $\mathrm{A} / \mathrm{P}$ ratio was 0.00009 . A smaller $\mathrm{A} / \mathrm{P}$ ratio showed that the adsorbent was able to adsorb a higher amount of antibiotic. As reported by [44], 
the amount of absorbed antibiotic (fluoroquinolone) increased with an increase in the concentration of nanoparticles (nanoMCN@MIPs).

HRT is another important parameter for determining the efficiency of the absorption process. Several studies have been carried out on the removal of different pollutants from water or wastewater using $\mathrm{ZnO}$ nanoparticles [35,38,45,46], with a different HRTs, which shows that this parameter is related to the type of pollutant. Figure $3 c$ shows the effect of HRT on the removal efficiency of antibiotics with $\mathrm{ZnO}$ nanoparticles. The results showed that by increasing the HRT from 5 to $10 \mathrm{~min}$, the antibiotic adsorption efficiency increased greatly, i.e., from 40 to $80 \%$. Hence, the highest antibiotic adsorption was at a HRT of $15 \mathrm{~min}$, i.e., $99.9 \%$.

Isotherms

To determine the rate of antibiotic adsorption on the surface of $\mathrm{ZnO}$ nanoparticles, isotherms such as Langmuir, Freundlich, D-R, Temkin, Genalized, and Jovian were used. The results of these isotherms are shown in Figure 4 and Table 1. Based on the results, the Langmuir equation with a correlation coefficient $\left(R^{2}\right)$ of 0.99 had the best $R^{2}$ in comparison to other isotherms. This means that the process of absorbing the antibiotic on the $\mathrm{ZnO}$ nanoparticles can be correctly fitted by the Langmuir equation. The constant coefficients $q_{\max }$ and $K_{m}$ in the Langmuir equation were $0.098 \mathrm{mg} / \mathrm{g}$ and $-20,242.91 \mathrm{~L} / \mathrm{mg}$, respectively. In addition, the separation parameter (S.F) was calculated using Equation (10):

$$
\text { S.F. }=\frac{1}{1+K_{L} C_{0}}
$$

where $C_{o}$ is the initial dye concentration (mg. $\mathrm{L}^{-1}$ ) and $K_{L}$ is related to the affinity of the binding sites. The S.F was 1 , showing that the adsorption process was linear [47]. 
Table 1. Constant coefficient of isotherms.

\begin{tabular}{|c|c|c|c|c|c|c|c|c|c|c|c|c|c|c|c|c|c|}
\hline \multicolumn{3}{|c|}{ Jovian } & \multicolumn{3}{|c|}{ Genalized } & \multicolumn{3}{|c|}{ D-R } & \multicolumn{3}{|c|}{ Temkin } & \multicolumn{3}{|c|}{ Freundlich } & \multicolumn{3}{|c|}{ Langmuir } \\
\hline $\mathrm{q}_{\max }$ & $K_{j}$ & $\mathbf{R}^{2}$ & $\mathbf{N}$ & $\mathrm{K}_{\mathrm{G}}$ & $\mathbf{R}^{2}$ & $\mathbf{q}_{\max }$ & $\beta$ & $\mathbf{R}^{2}$ & $\mathbf{K}_{\mathrm{T}}$ & $\mathrm{B}_{1}$ & $\mathbf{R}^{2}$ & $k_{f}$ & $\mathbf{n}$ & $\mathbf{R}^{2}$ & $\mathrm{q}_{\mathrm{m}}$ & $K_{e}$ & $\mathbf{R}^{2}$ \\
\hline 116.33 & 0.002 & 0.6074 & 0.2008 & 0.10856 & 0.6199 & $4.3 \times 10^{43}$ & $3 \times 10^{-8}$ & 0.15 & $3.11 \times 10^{-87}$ & 0.5242 & 0.0191 & 0.99 & -263.2 & 0.012 & 0.098 & -20242.91 & 0.99 \\
\hline
\end{tabular}




\subsection{UV Radiation}

Different amounts of antibiotic were removed at different $\mathrm{pHs}$ using UV radiation (Figure 5a). The results showed that the antibiotic removal efficiency was $41 \%$ when the $\mathrm{pH}$ was in the range of 2 to 11 . By increasing the $\mathrm{pH}$ from 11 to 13 , the efficiency of antibiotic removal was reduced from $41 \%$ to $15 \%$ using UV radiation. As reported by [48], an increase of $\mathrm{pH}$ causes an increase in the removal efficiency of organic compounds and hydrogen sulfide by UV radiation. Moreover, [32] found that the optimal $\mathrm{pH}$ for the removal of 1, 9-Dimethyl-Methylene Blue Zinc Chloride Double Salt by UV irradiation was in the range of 9.8 to 13.5 .

In acidic pHs, UV light produces free radicals on the surface of the antibiotic. This means that etheric oxygen containing nonbonding electron pairs would be positive due to the loss of one electron. For this reason, the etheric oxygen gains its bonding electron and the bond between the carbon of the chair structure and the etheric oxygen would be broken. However, in basic $\mathrm{pHs}$, the concentration of $\mathrm{OH}^{-}$is increased. So, $\mathrm{UV}$ light attacks the nonbonding electron of $\mathrm{OH}^{-}$instead of the nonbonding electron of the etheric oxygen. It can be concluded that $\mathrm{OH}^{-}$prevents the attack of UV light upon etheric oxygen at high concentration and high pHs. Therefore, the removal efficiency of the antibiotic could be decreased. It is to be expected that the broken of etheric bond increases with an increase of temperature and entropy in the presence of UV light [42,45,46,49].

Temperature can also be considered an effective parameter on the removal of the antibiotic from the ASCA. The effect of temperature is shown in Figure $5 \mathrm{~b}$. Based on the results, the removal efficiencies at $25^{\circ} \mathrm{C}$ and $65{ }^{\circ} \mathrm{C}$ were $41 \%$ and $73 \%$, respectively. It can be concluded that increasing the temperature had a significant effect on antibiotic removal efficiency. In addition, increasing the HRT from 20 to $60 \mathrm{~min}$ had a significant effect on the removal efficiency. However, with an increase of HRT to more than $60 \mathrm{~min}$, there was no significant increase in antibiotic removal (Figure 5c).

$\mathrm{UV}$ radiation is also an effective parameter in the removal of organic compounds such as antibiotics from water [50]. The results showed that increasing UV radiation resulted in an increase in the removal efficiency of antibiotic from the ASCA (Figure 5d). Under UV radiation of $103 \mathrm{~mW} / \mathrm{cm}^{2}$, the removal efficiency was $32 \%$. Meanwhile, by increasing the UV-radiation power to $163 \mathrm{~mW} / \mathrm{cm}^{2}$, the removal efficiency reached $41 \%$. Some other studies have shown that increasing UV power could strongly increase the pollutant removal efficacy [48]. For instance, the photo-electro-Fenton process can be used for the removal of metronidazole from wastewater. By increasing the $\mathrm{pH}$, electric current intensity, UV irradiation and metronidazole concentration, the removal efficiency is increased [51].

\subsection{Fe (VI) Oxidation Process}

Advanced oxidation processes are a set of chemical treatment procedures designed to remove organic materials from water by oxidation through reactions with hydroxyl radicals. $\mathrm{pH}$ is one of the most important parameters affecting chemical reactions in this method [48]. The results showed that increasing the $\mathrm{pH}$ was an important parameter in the removal of antibiotic by the $\mathrm{Fe}(\mathrm{VI})$ oxidation process. The efficiency of antibiotic removal from wastewater by $\mathrm{Fe}(\mathrm{VI})$ at $\mathrm{pH} 2$ was $65 \%$. By increasing the $\mathrm{pH}$ to 12 , the antibiotic removal efficiency was reduced to $10 \%$ (Figure $6 \mathrm{a}$ ). The relationship between $\mathrm{pH}$ and antibiotic removal efficiency by Fe (VI) can be described using the equation $\mathrm{y}=-0.0509 \mathrm{x}+0.716$ with an $R^{2}$ of 0.95 . Several studies have reported similar results for the removal of hydrogen sulfide and organic compounds from domestic wastewater and formaldehyde from synthetic wastewater using Fe (VI) [48,52].

While Fe (VI) in acidic conditions has good potential for the removal of organic compounds from the wastewater, the cost of $\mathrm{pH}$ reduction is very high [53]. As calculated by [53], the cost of a $\mathrm{pH}$ reduction of one $\mathrm{m}^{3}$ of domestic wastewater using sulfuric acid is approximately $2.52 \$$.

$$
\text { Iron electrode } \stackrel{\text { Electrolysis+NaOH }}{\longrightarrow} \text { Ferrate }(V I)
$$


$\mathrm{Fe}$ (VI) can be electrochemically produced in two forms: $\mathrm{FeO}_{4}{ }^{-2}$ and $\mathrm{HFeO}_{4}{ }^{-}$(Equations (11) and (12)). The consumption rate of each can be calculated by Equation (12). In this equation, $\mathrm{K}_{1}$ and $\mathrm{K}_{2}$ are the constants of the consumption of $\mathrm{HFeO}_{4}{ }^{-}$and $\mathrm{FeO}_{4}{ }^{-2}$.

$$
\mathrm{K}[\text { Ferrate }]=\mathrm{K}_{1}\left[\mathrm{HFeO}_{4}^{-}\right]+\mathrm{K}_{2}\left[\mathrm{FeO}_{4}^{2-}\right]
$$

The constant rates of consumption of $\mathrm{FeO}_{4}{ }^{-2}$ and $\mathrm{HFeO}_{4}{ }^{-}$are $1.24 \times 10^{2} \mathrm{M} / \mathrm{s}$ and $8.41 \times 10^{2} \mathrm{M} / \mathrm{s}$, respectively. As a result, the reaction rate between the antibiotic and $\mathrm{HFeO}_{4}{ }^{-}$was higher than that of $\mathrm{FeO}_{4}{ }^{-2}$. Therefore, $\mathrm{HFeO}_{4}{ }^{-}$had a significant effect on antibiotic removal from the wastewater. Since in acidic conditions, the dominant formation of $\mathrm{Fe}(\mathrm{VI})$ is $\mathrm{HFeO}_{4}{ }^{-}$, antibiotic removal under acidic conditions was better than under alkaline condition.

The results showed that changing the temperature from $25{ }^{\circ} \mathrm{C}$ to $60^{\circ} \mathrm{C}$ had little effect on the removal efficiency by the $\mathrm{Fe}(\mathrm{VI})$ oxidation process (Figure 6b). Increasing the temperature from $25^{\circ} \mathrm{C}$ to $60^{\circ} \mathrm{C}$ could lead to an increase in the antibiotic removal efficiency from $90 \%$ to $100 \%$. Increasing HRT from 10 to $20 \mathrm{~min}$ increased the removal efficiency from $45 \%$ to $95 \%$ (Figure 6c). However, there was no significant effect on antibiotic removal by Fe (VI) when the HRT was increased to more than 20 min.

The concentration of $\mathrm{Fe}(\mathrm{VI})$ is also another important parameters in the removal of antibiotics from synthetic wastewater [50]. Increasing the concentration of Fe (VI) from 1 to $4 \mathrm{mg} / \mathrm{L}$ increased the antibiotic removal efficiency. However, by increasing the Fe (VI) concentration to more than $4 \mathrm{mg} / \mathrm{L}$, the antibiotic removal efficiency was not significantly increased (Figure 6d). Reporting the optimal A/P instant of the Fe (VI) concentration is a better strategy for industrial applications. The results showed that the optimal $\mathrm{A} / \mathrm{P}$ was 0.011 to 0.012 , and that $\mathrm{Fe}(\mathrm{VI})$ is a suitable method to remove azithromycin from wastewater. It is important that this method be used to remove other common antibiotics in real samples of wastewater to properly understand all of its advantages and disadvantages. Then, the $\mathrm{Fe}(\mathrm{VI})$ oxidation process can be applied on a large scale to remove a mixture of different antibiotics.

\section{Conclusions}

In this study, the removal of the antibiotic azithromycin from synthetic wastewater by three different methods, namely Fe (VI) oxidation, UV irradiation and absorption by ZnO nanoparticles, was investigated. It was found that the efficiencies of antibiotic removal by Fe (VI) oxidation, UV irradiation and absorption by $\mathrm{ZnO}$ nanoparticles were $100 \%, 73 \%$, and $100 \%$, respectively. In addition, reducing the $\mathrm{pH}$ led to a sharp increase in the removal efficiency by the Fe (VI) oxidation process. By increasing HRT up to $20 \mathrm{~min}$, the antibiotic removal efficiency increased, while higher HRTs had no significant effect on removal efficiency. Also, the effect of temperature on the removal efficiency was low using the Fe (VI) oxidation process. The optimal ratio of Fe (VI) concentration to the initial concentration of antibiotic was 0.011 and 0.012 . Increasing the temperature to $60^{\circ} \mathrm{C}$ had a positive effect on the removal efficiency by UV radiation and $\mathrm{ZnO}$ nanoparticles. For future studies, the investigation of a combination of the $\mathrm{Fe}(\mathrm{VI})$ oxidation process, $\mathrm{UV}$ radiation and $\mathrm{ZnO}$ nanoparticles is recommended.

Author Contributions: Writing, Review \& Editing, and Data curation: A.T., Writing—original draft, experimental, Data collection: S.J. Providing study material, Review \& Editing, Data curation: F.B. Writing-review \& editing, Data curation: Z.E. Writing, Data curation: J.C. Software, Data curation, G.M. Supervision, Validation, financial support: S.R. All authors have read and agreed to the published version of the manuscript.

Funding: This research received no external funding.

Acknowledgments: This article has been written from the dissertation of Sahar Joudaki in the field of chemical engineering at Jami Institute of Technology, Isfahan, Iran. The authors of this article appreciate Jami Institute of Technology for its financial and moral support, which led to the completion of this dissertation.

Conflicts of Interest: The authors declare no conflict of interest. 


\section{References}

1. Yadav, K.K.; Kumar, S.; Pham, Q.B.; Gupta, N.; Rezania, S.; Kamyab, H.; Yadav, S.; Vymazal, J.; Kumar, V.; Tri, D.Q.; et al. Fluoride contamination, health problems and remediation methods in Asian groundwater: A comprehensive review. Ecotoxicol. Environ. Saf. 2019, 182, 109362. [CrossRef]

2. Nateghian, Z.; Aliabadi, E. Aspects of Environmental Pollutants on Male Fertility and Sperm Parameters. J. Environ. Treat. Tech. 2020, 8, 299-309.

3. Aigberua, A.; Tarawou, T. Water Quality Index (WQI) Assessment along Inland Fresh Waters of Taylor Creek in Bayelsa State, Nigeria. J. Environ. Treat. Tech. 2019, 7, 260-269.

4. Gadipelly, C.; Pérez-González, A.; Yadav, G.D.; Ortiz, I.; Ibáñez, R.; Rathod, V.K.; Marathe, K.V. Pharmaceutical industry wastewater: Review of the technologies for water treatment and reuse. Ind. Eng. Chem. Res. 2014, 53, 11571-11592. [CrossRef]

5. Mellah, A.; Harik, D. Removal Pharmaceutical Pollutants by Adsorption Competitive using Powdered Activated Carbon CAP (F400). J. Environ. Treat. Tech. 2020, 8, 336-345.

6. Ahmed, M.B.; Zhou, J.L.; Ngo, H.H.; Guo, W.; Thomaidis, N.S.; Xu, J. Progress in the biological and chemical treatment technologies for emerging contaminant removal from wastewater: A critical review. J. Hazard. Mater. 2017, 323, 274-298. [CrossRef]

7. Acar, J.F. Consequences of bacterial resistance to antibiotics in medical practice. Clin. Infect. Dis. 1997, 24 (Suppl. 1), S17-S18. [CrossRef]

8. Tolls, J. Sorption of Veterinary Pharmaceuticals in Soils: A Review. Environ. Sci. Technol. 2001, 35, 3397-3406. [CrossRef]

9. Wei, R.; Ge, F.; Huang, S.; Chen, M.; Wang, R. Occurrence of veterinary antibiotics in animal wastewater and surface water around farms in Jiangsu Province, China. Chemosphere 2011, 82, 1408-1414. [CrossRef]

10. Yang, S.; Cha, J.; Carlson, K. Simultaneous extraction and analysis of 11 tetracycline and sulfonamide antibiotics in influent and effluent domestic wastewater by solid-phase extraction and liquid chromatography-electrospray ionization tandem mass spectrometry. J. Chromatogr. A 2005, 1097, 40-53. [CrossRef]

11. Bhandari, A.; Close, L.I.; Kim, W.; Hunter, R.P.; Koch, D.E.; Surampalli, R.Y. Occurrence of ciprofloxacin, sulfamethoxazole, and azithromycin in municipal wastewater treatment plants. Pract. Period. Hazard. Toxic Radioact. Waste Manag. 2008, 12, 275-281. [CrossRef]

12. Mowery, H.; Loganathan, B. Persistent organic compounds in wastewater: Azithromycin and urobilin concentrations in wastewater treatment plant samples from Murray, Kentucky, USA. Organohalogen Compd. 2007, 69, 483.

13. Fair, R.J.; Tor, Y. Antibiotics and bacterial resistance in the 21st century. Perspect. Medicin. Chem. 2014, 6, PMC. S14459. [CrossRef]

14. Baran, W.; Adamek, E.; Jajko, M.; Sobczak, A. Removal of veterinary antibiotics from wastewater by electrocoagulation. Chemosphere 2018, 194, 381-389. [CrossRef] [PubMed]

15. Raghavan, D.S.S.; Qiu, G.; Ting, Y.-P. Fate and removal of selected antibiotics in an osmotic membrane bioreactor. Chem. Eng. J. 2018, 334, 198-205. [CrossRef]

16. Karaolia, P.; Michael-Kordatou, I.; Hapeshi, E.; Alexander, J.; Schwartz, T.; Fatta-Kassinos, D. Investigation of the potential of a Membrane BioReactor followed by solar Fenton oxidation to remove antibiotic-related microcontaminants. Chem. Eng. J. 2017, 310, 491-502. [CrossRef]

17. Norte, T.H.d.O.; Marcelino, R.B.P.; Medeiros, F.H.A.; Moreira, R.P.L.; Amorim, C.C.; Lago, R.M. Ozone oxidation of $\beta$-lactam antibiotic molecules and toxicity decrease in aqueous solution and industrial wastewaters heavily contaminated. Ozone Sci. Eng. 2018, 40, 385-391. [CrossRef]

18. Li, B.; Zhang, T. Different removal behaviours of multiple trace antibiotics in municipal wastewater chlorination. Water Res. 2013, 47, 2970-2982. [CrossRef]

19. Ternes, T.A.; Stüber, J.; Herrmann, N.; McDowell, D.; Ried, A.; Kampmann, M.; Teiser, B. Ozonation: A tool for removal of pharmaceuticals, contrast media and musk fragrances from wastewater? Water Res. 2003, 37, 1976-1982. [CrossRef]

20. Hey, G.; Grabic, R.; Ledin, A.; La Cour Jansen, J.; Andersen, H. Oxidation of pharmaceuticals by chlorine dioxide in biologically treated wastewater. Chem. Eng. J. 2012, 185, 236-242. [CrossRef] 
21. Audino, F.; Toro Santamaria, J.M.; Del Valle Mendoza, L.J.; Graells, M.; Pérez-Moya, M. Removal of paracetamol using effective advanced oxidation processes. Int. J. Environ. Res. Public Health 2019, 16, 505. [CrossRef]

22. Sharma, V.K.; Liu, F.; Tolan, S.; Sohn, M.; Kim, H.; Oturan, M.A. Oxidation of $\beta$-lactam antibiotics by ferrate (VI). Chem. Eng. J. 2013, 221, 446-451. [CrossRef]

23. Musikavong, C.; Wattanachira, S.; Marhaba, T.F.; Pavasant, P. Reduction of organic matter and trihalomethane formation potential in reclaimed water from treated industrial estate wastewater by coagulation. J. Hazard. Mater. 2005, 127, 48-57. [CrossRef]

24. Talaiekhozani, A.; Talaei, M.R.; Rezania, S. An Overview on Production and Application of Ferrate (VI) for Chemical Oxidation, Coagulation and Disinfection of Water and Wastewater. J. Environ. Chem. Eng. 2017, 5, 1828-1842. [CrossRef]

25. Zhang, H.; Zheng, L.; Li, Z.; Pi, K.; Deng, Y. One-step Ferrate(VI) treatment as a core process for alternative drinking water treatment. Chemosphere 2020, 242, 125134. [CrossRef] [PubMed]

26. Machala, L.; Zajíček, P.; Kolařík, J.; Mackul'ak, T.; Filip, J. Ferrates as Powerful Oxidants in Water Treatment Technologies. In Advanced Nano-Bio Technologies for Water and Soil Treatment; Filip, J., Cajthaml, T., Najmanová, P., Černík, M., Zbořil, R., Eds.; Springer International Publishing: Cham, The Netherlands, 2020; pp. 177-201.

27. Gholami, M.; Mohammadi, M.; Zare-Hoseinabadi, A.; Taghizadeh, S.; Behzad Behbahani, A.; Arab Solghar, R.; Amani, A.M. Preparation of ZnXFe3-XO4@chitosan Nanoparticles As an Adsorbent for Methyl Orange and Phenol. J. Environ. Treat. Tech. 2019, 7, 245-249.

28. Dayang, W.; Dongbo, P. Taurine prevents ultraviolet B induced apoptosis in retinal ganglion cells. Cutan. Ocul. Toxicol. 2018, 37, 90-95. [CrossRef] [PubMed]

29. Norouzi, K. Modeling of Adsorption in a Packed Bed Tower, the Case Study of Methane Removal and Parametric Calculation. J. Environ. Treat. Tech. 2019, 7, 324-333.

30. Jin, L.; Chai, L.; Yang, W.; Wang, H.; Zhang, L. Two-Dimensional Titanium Carbides (Ti3C2Tx) Functionalized by Poly (m-phenylenediamine) for Efficient Adsorption and Reduction of Hexavalent Chromium. Int. J. Environ. Res. Public Health 2020, 17, 167. [CrossRef]

31. Asha, E.; Parveen Fatemeh, R.; Kar Woon, L.; Mohd Hafiz, J.; Mohd Azrul, N.; Sun, J.S.; Shao, W.; Ismail, S. Treatment of Dye Wastewater by Functionalization of Bentonite-Methylene Blue with Sodium Persulfate. J. Environ. Treat. Tech. 2019, 7, 229-233.

32. Talaiekhozani, A.; Banisharif, F.; Eskandari, Z.; Talaei, M.R.; Park, J.; Rezania, S. Kinetic Investigation of 1, 9-Dimethyl-Methylene Blue Zinc Chloride Double Salt Removal from Wastewater using Ferrate (VI) and Ultraviolet Radiation. JKSUS 2020, 32, 213-222. [CrossRef]

33. Eskandari, Z.; Talaiekhozani, A.; Talaie, M.R.; Banisharif, F. Enhancing ferrate(VI) oxidation process to remove blue 203 from wastewater utilizing MgO nanoparticles. J. Environ. Manag. 2019, 231, 297-302. [CrossRef] [PubMed]

34. Federation, W.E.; Association, A.P.H. Standard Methods for the Examination of Water and Wastewater; American Public Health Association (APHA): Washington, DC, USA, 2005.

35. Moussavi, G.; Mahmoudi, M. Removal of azo and anthraquinone reactive dyes from industrial wastewaters using MgO nanoparticles. J. Hazard. Mater. 2009, 168, 806-812. [CrossRef] [PubMed]

36. Collings, P.J.; Hird, M. Introduction to Liquid Crystals: Chemistry and Physics; CRC Press: London, UK, 2017.

37. Anslyn, E.V.; Dougherty, D.A. Modern Physical Organic Chemistry; University Science Books: Mill Valley, CA, USA, 2006.

38. El-Kemary, M.; El-Shamy, H.; El-Mehasseb, I. Photocatalytic degradation of ciprofloxacin drug in water using ZnO nanoparticles. J. Lumin. 2010, 130, 2327-2331. [CrossRef]

39. Agarwal, M.; Dave, M.; Upadhayaya, S. Adsorption of Formaldehyde on Treated Activated Carbon and Activated Alumina. Curr. World. Environ. 2011, 6, 53-59. [CrossRef]

40. Mohamad Amran, M.S.; Dalia Khalid, M.; Wan Azlina, W.A.K.; Azni, I. Cationic and anionic dye adsorption by agricultural solid wastes: A comprehensive review. Desalination 2011, 280, 1-13.

41. Hudlicky, M. Oxidations in Organic Chemistry; American Chemical Society: Washington, DC, USA, 1990.

42. Elmolla, E.S.; Chaudhuri, M. Comparison of different advanced oxidation processes for treatment of antibiotic aqueous solution. Desalination 2010, 256, 43-47. [CrossRef] 
43. Wang, L.; Hu, C.; Shao, L. The antimicrobial activity of nanoparticles: Present situation and prospects for the future. Int. J. Nanomed. 2017, 12, 1227. [CrossRef]

44. Tan, F.; Sun, D.; Gao, J.; Zhao, Q.; Wang, X.; Teng, F.; Quan, X.; Chen, J. Preparation of molecularly imprinted polymer nanoparticles for selective removal of fluoroquinolone antibiotics in aqueous solution. J. Hazard. Mater. 2013, 244, 750-757. [CrossRef]

45. Eslami, A.; Nasseri, S.; Yadollahi, B.; Mesdaghinia, A.; Vaezi, F.; Nabizadeh, R.; Nazmara, S. Photocatalytic degradation of methyl tert-butyl ether (MTBE) in contaminated water by ZnO nanoparticles. J. Chem. Technol. Biotechnol. 2008, 83, 1447-1453. [CrossRef]

46. Hariharan, C. Photocatalytic degradation of organic contaminants in water by ZnO nanoparticles: Revisited. Appl. Catal. A Gen. 2006, 304, 55-61. [CrossRef]

47. Kaur, S.; Rani, S.; Mahajan, R.K. Adsorption kinetics for the removal of hazardous dye congo red by biowaste materials as adsorbents. J. Chem. 2012, 2013. [CrossRef]

48. Talaiekhozani, A.; Eskandari, Z.; Talaei, M.R.; Salari, M. Hydrogen sulfide and organic compounds removal in municipal wastewater using ferrate (VI) and ultraviolet radiation. Environ. Health Eng. Manag. J. 2017, 4, 7-14. [CrossRef]

49. Liu, X.; Zhang, T.; Zhou, Y.; Fang, L.; Shao, Y. Degradation of atenolol by UV/peroxymonosulfate: Kinetics, effect of operational parameters and mechanism. Chemosphere 2013, 93, 2717-2724. [CrossRef]

50. Talaiekhozani, A.; Eskandari, Z.; Bagheri, M.; Talaie, M.R. Removal of H2S and COD Using UV, Ferrate and UV/Ferrate from Municipal Wastewater. J. Hum. Environ. Health Promot. 2016, 2, 1-8. [CrossRef]

51. Kamarehie, B.; Ahmadi, F.; Hafezi, F.; Abbariki, A.; Heydari, R.; Karami, M.A. Experimental data of electric coagulation and photo-electro-phenton process efficiency in the removal of metronidazole antibiotic from aqueous solution. Data Brief 2018, 18, 96-101. [CrossRef]

52. Talaiekhozani, A.; Salari, M.; Talaei, M.R.; Bagheri, M.; Eskandari, Z. Formaldehyde removal from wastewater and air by using UV, ferrate (VI) and UV/ferrate (VI). J. Environ. Manag. 2016, 184, 204-209. [CrossRef]

53. Talaiekhozani, A.; Eskandari, Z.; Rodpeyma, S.; Bagheri, M. Design and Development of Municipal Wastewater Treatment Systems by Fe (VI) and Computation of System's Economic Navigation. J. Adv. Med Sci. Appl. Technol. 2017, 3, 169-174. [CrossRef]

(C) 2020 by the authors. Licensee MDPI, Basel, Switzerland. This article is an open access article distributed under the terms and conditions of the Creative Commons Attribution (CC BY) license (http://creativecommons.org/licenses/by/4.0/). 